Meta

Journal des traducteurs

Translators' Journal

\title{
Banking on Terminology Conference Interpreters in the Electronic Age
}

\section{Barbara Moser-Mercer}

Volume 37, numéro 3, septembre 1992

URI : https://id.erudit.org/iderudit/003634ar

DOI : https://doi.org/10.7202/003634ar

Aller au sommaire du numéro

\section{Éditeur(s)}

Les Presses de l'Université de Montréal

ISSN

0026-0452 (imprimé)

1492-1421 (numérique)

Découvrir la revue

Citer cet article

Moser-Mercer, B. (1992). Banking on Terminology Conference Interpreters in the Electronic Age. Meta, 37(3), 507-522. https://doi.org/10.7202/003634ar

\section{Résumé de l'article}

De nombreux efforts ont été faits afin de concevoir des protocoles à suivre en documentation terminologique, mais on a toujours cru que les besoins des interprètes étaient les mêmes que ceux des traducteurs et des terminologues. Bien que ces professionnels soient tous d'accord pour reconnaître l'importance du mot juste, souvent ils n'ont pas accès à l'information terminologique par les mêmes moyens. Le présent article brosse un tableau des différences relevées dans la méthodologie de la recherche documentaire chez les traducteurs et les interprètes. L'information sur les besoins terminologiques des interprètes a été rassemblée à l'aide d'un questionnaire distribué aux membres de l'Association internationale des interprètes de conférence et les analyses statistiques sont présentées avec des références spécifiques aux données terminologiques, à la gestion de la documentation et aux échanges de données entre interprètes. 


\title{
BANKING ON TERMINOLOGY CONFERENCE INTERPRETERS IN THE ELECTRONIC AGE
}

BARBARA MOSER-MERCER École de traduction et d' interprétation Université de Genève, Genève, Suisse

\begin{abstract}
Résumé
De nombreux efforts ont été faits afin de concevoir des protocoles à suivre en documentation terminologique, mais on a toujours cru que les besoins des interprètes étaient les mêmes que ceux des traducteurs et des terminologues. Bien que ces professionnels soient tous d'accord pour reconnaître l'importance du mot juste, souvent ils n'ont pas accès à l'information terminologique par les mêmes moyens.

Le présent article brosse un tableau des différences relevées dans la méthodologie de la recherche documentaire chez les traducteurs et les interprètes. L'information sur les besoins terminologiques des interprètes a été rassemblée à l'aide d'un questionnaire distribué aux membres de l'Association internationale des interprètes de conférence et les analyses statistiques sont présentées avec des références spécifiques aux données terminologiques, à la gestion de la documentation et aux échanges de données entre interprètes.
\end{abstract}

ABSTRACT

Considerable effort has already been spent on devising terminology documentation guidelines and it has always been assumed that interpreters' needs are identical to those of translators and terminologists. While members of the three professions are all agreed on the need for the proper term and/or phrase to denote an object or an idea, considerable differences exist in the way these professionals gain access to terminological information.

This paper sketches the differences in the flow of work of translators and interpreters. Information on interprters' terminological needs was gathered by means of a questionnaire sent out to members of the International Association of Conference Interpreters (AIIC) and the statistical analyses are presented with specific reference to terminological data elements, documentation control and data exchange among conference interpreters. ${ }^{1}$

\section{INTRODUCTION}

Much attention has been devoted to translators in the electronic age. The translator's workstation of today offers the entire gamut of electronic tools, from word processing to grammar checking and terminology databank software, with a series of software packages designed specifically for use by translators. It is by way of exception, then, that interpreters - quite used to more "visibility" than their colleagues in translation - have by and large not benefitted from these technological advances, perhaps mostly because available products have not really met their needs, and in part because they represent a rather small market segment.

The purpose of this study was to survey how conference interpreters handle terminology documentation and document control and to offer some guidelines as to the development of interpretation-specific software tools for terminology and documentation management. 
What a decade ago was handled exclusively by large databanks implemented in a mainframe environment has today become available on PCs and even notebook computers. There are software packages for entering and syntactic checking of terminological and phraseological data. Entries can be sorted alphabetically within each language, by subject field, source or date of entry; phraseological information can be found under key words. Entries can be retrieved according to any criterion, by term, language, subject field, date of entry, reliability, author, or any combination thereof, in any format desired. Conference interpreters have access to knowledge and terminology data bases via ISDN, the standardization of multilingual terminology documentation allows them to exchange their terminology with colleagues all over the world and terminology for a specific subject field is available at low cost from dictionary publishers or conference organizers. This is not science fiction! From a technological point of view nothing prevents us from making the above standard practice. It is, in this day and age of information, often a lack of information that prevents us from exploiting technological innovations.

\section{TERMINOLOGY DATABANKS (TDBS)}

Some of the major databanks such as EURODICAUTOM and TERMIUM have been with us for quite some time. Others have been developed over the past decade to meet the growing needs of translators and documentation specialists. International efforts on the part of ISO and more informal contacts among databank operators have produced guidelines for the exchange of terminological and lexicographical records ( $c f$. International Standard ISO 6156, MATER). Such attempts at standardization have benefitted mainly translators working in language services of international organizations or governments. With its 60 categories, MATER is a rather complex document and goes beyond the day-to-day needs of a free-lance translator. Many of the PC-based TDBs such as Superlex, Profilex, Term-Tracer and Termex operate with a much smaller number of categories; here the aim has been the integration into a word-processing environment and compatibility with other software tools available to the translator rather than the simulation of a large TDB.

\section{THE TRANSLATOR'S WORK FLOW}

Working at his modern workstation, today's translator after having received the original text from his client in electronic form will be able to scan the document for technical terminology, update his computer-based TDB either by checking paper dictionaries or other paper-based references, experts and large TDBs and data bases, then proceed with the translation of the text on screen, with the original text scrolling in a separate window and terminology being pasted in from another window. After completion of the translation he will submit the entire text to a grammar and spell-checker, format the text according to the client's specifications or channel it through the desktop publishing service if he works in an agency or larger language service. Chances are he will not print the translation but return it to the client via modem or on a diskette. Of course, this is but one possible scenario, yet it captures the translator's work flow without going into considerable detail or variations.

\section{THE INTERPRETER'S WORK FLOW}

The conference interpreter's work begins the moment she accepts a contract for a conference. The general conditions of work as laid down in the standard AIIC contract stipulate that "for their technical and terminological preparation the organizer shall send the interpreters a complete set of documents (programme, agenda, minutes of the previous meeting, reports, etc.) in each of the working languages of the conference as early as 
possible, but not later than 15 days before the beginning of the conference." Although there is no universally accepted mode of preparation, most interpreters will read through the material provided (or pertinent literature if no material has been provided), underline unfamiliar terms and phrases and search for equivalents in their other working languages. As a next step interpreters will usually establish terminology lists with source language terms down the left margin and center of the page and target language equivalents down the right margin. Disregarding for the moment the more careful preparation of certain papers and speeches, these word lists, either prepared manually or on the computer, are then studied and constitute, together with essential subject preparation, the knowledge basis for the upcoming conference. During a briefing session shortly before the conference, or during the conference and as papers are read and discussions with colleagues and perhaps delegates continue on the subject, word lists are updated, poor equivalents replaced by better ones or those preferred by a particular organization. At the end of a conference, conscientious interpreters will polish the list of terms, perhaps even print it out in its updated form and file it away, sometimes together with certain conference documents, if they had been allowed to take them from the booth.

While both translator and interpreter have access to a wide variety of resources, the interpreter's access to these materials becomes extremely limited once he is in the booth. Whereas translators - time constraints permitting - can go back to a large variety of reference works and sources, interpreters usually cannot during their time in the booth. This constitutes an essential difference in the way interpreters make use of resources: they have to glean the required information from the source and then keep it on file either in the form of a list of terms or as a note on a particular paper to be read or filed away as a general note they will take along to the conference. At the conference venue further information is added: new terms are acquired, etc. The interpreter's acquisition of information can thus be viewed as a continuous process, with terminological equivalents refined often until the very last moment before embarking on the interpretation of a speech or scientific paper.

\section{THE STUDY}

\subsection{Interpreter profile}

To examine in greater detail the terminology and documentation needs of conference interpreters a questionnaire was designed that addressed these aspects of an interpreter's work. It was distributed among 260 conference interpreters around the world, all active members of AIIC. The only two characteristics all had to have in common were that they had to be active members of the organization and English had to be one of their working languages, since the questionnaire was worded in English. The return rate was exceptionnaly high when compared to the standard return rate in social science research (10\%): Of the 80 questionnaires distributed at a meeting of AIIC members working in the non-agreement sector in July 1991 in Prague, 27 were returned, and of the 180 sent out shortly thereafter, 95 were returned. This represents an overall return rate of $47 \%$. A separate survey was carried out in Japan (see point 6); of the 12 questionnaires distributed, 8 were returned, which represents a return rate of $67 \%$.

The following graphs provide a profile of the interpreters surveyed according to how long they have exercised the profession (graph 1), how many days a year they work (graph 2), and whether they have access to a computer (graph 3). These variables were chosen because it was felt they they had a direct influence on interpreters' terminology and documentation habits.

Also of interest was shedding some light on the issue of interpreter generalist versus interpreter specialist. 52,5\% of all respondents have fields of specialization (graph 4), 
mostly developed during $(57,6 \%)$, before and during $(39,4 \%)$ or before $(3 \%)$ their professional practice. $50,8 \%$ of those who responded that they developed fields of specialization are seasoned interpreters with more than 21 years in the profession and $49 \%$ work between 100 and 200 days a year.

The fact that computer use and number of years in the profession as well as number of days worked per year are similarly correlated (see below) suggests that the more years an interpreter has spent in the profession and the more days he or she works per year the greater the likelihood for fields of specialization having been developed, for data processing tools being used and for electronic solutions being sought.

However, when interpreters were asked whether they had ever turned down a conference for technical complexity of the subject matter involved, no such correlation between years in the profession/days worked per year was found: $46 \%$ answered positively, with a similarly balanced distribution appearing in all categories.

\subsection{Documentation}

The next set of graphs provides insight into how interpreters tend to document themselves (graph 5), what documents they receive from the organizer (graph 6) and whether they participate in briefing sessions (graph 7) and finally how they manage their documents (graphs 8,9 and 10). The importance of document control is often overlooked in conference interpreting. It emerges clearly from the results of the questionnaire, though, that $79 \%$ of the respondents ranked papers to be read at the conference as extremely important for their terminology research, $87,3 \%$ keep papers of past conferences, if allowed to take them from the booth, and all use some classification system, $64 \%$ by subject matter, $13 \%$ by client, $17 \%$ by subject matter and client and the remaining $5 \%$ alphabetically or in a combination of the above. $67 \%$ of the respondents are interested in software with which to organize their documents (graph 11).

The next graph (12) illustrates the importance of particular resources to the interpreter's preparation. As indicated above, papers to be read at the conference emerge as the most important resource for terminology research (79\% of all respondents consider them very important), followed by personal terminology lists $(66 \%)$, client-supplied terminology lists $(54 \%)$, bilingual dictionaries $(49 \%)$, personal terminology databases on computer $(40 \%)$, monolingual dictionaries $(39 \%)$ and glossaries (38\%). External TDBs and external data bases emerged as the least useful resources and this was confirmed through responses given to another (control) question regarding interpreters accessing TDBs: only 3,6\% access external TDBs, though 54,5\%, express a distinct interest in doing so in the future (graph 13).

\subsection{Degree of computerization}

The survey revealed the degree of computerization in the profession: $62,3 \%$ either have a computer or access to one (graph 3 ), which in $37,3 \%$ of all cases is a portable computer. $51,3 \%$ of computer users run software other than word processing (graph 14): $35,5 \%$ use data base software, $40 \%$ termonology databank software, $31 \%$ use spreadsheets, $46,5 \%$ use desktop publishing software, most likely those who translate in addition to interpreting (graph 15). The cross-tabulations between years in the profession (an indicator of biological age) and computer use indicates that in the category $>21$ years in the profession $36 \%$ are computer users versus only $7 \%$ in the category $6-10$ years in the profession. A similar trend can be observed for days worked per year and computer use: The highest percentage of computer users is found in the category 100 - 200 days worked per year $(33 \%)$; significantly more days worked $(200-300)$ do not promote computer use, however. This may be explained by the fact that permanent interpreters probably 
made up the bulk of the category 200 - 300 days worked per year and most international organizations are not nearly as well equipped electronically as the private market tends to be.

\section{SURVEY OF JAPANESE CONFERENCE INTERPRETERS}

The same questionnaire was used to survey conference interpreters in Japan. The responses given to most questions followed trends very similar to those found in the general sample and outlined above. Differences were seen only with regard to documentation, with all Japanese interpreters responding positively to receiving documents before the conference, generally $3-5$ days in advance. $75 \%$ participate in briefing sessions often (versus only $1,7 \%$ in the general sample), which makes advance documentation an outstanding practice in Japan. Differences were also seen in computer use, with only $25 \%$ (versus $62,3 \%$ in the general sample) using or having access to a computer. None of the Japanese interpreters access large TDBs, as was to be expected, although $37,5 \%$ (versus $54,5 \%$ in the general sample) expressed interest in doing so.

Due to the small sample size the values given for Japan obviously are not as reliable as those for the general sample, yet it is interesting to single out one region with a different writing system and to observe the potential impact on document management.

\section{SOME RECOMMENDATIONS ON TERMINOLOGY AND DOCUMENTATION} SOFTWARE FOR INTERPRETERS

With $72,7 \%$ of all respondents interested in exchanging terminology in electronic form - the highest percentage was found with interpreters who have been in the profession between 11 and 20 years (38\%) and those who work between 100 and 200 days $(31 \%)$ - and $67 \%$ wanting to use software for organizing their documents (graph 11), a rather clear message emerges: software developers targeting the conference interpreting market must provide a tool that meets the specific needs of the interpreters and not just market translation tools.

The following graphs $(16,17)$ reveal some of the information interpreters would like to see included as well as some of the functions they would like to see implemented in such a software package.

The capabilities and functions requested most frequently by interpreters as well as of course the interpreter's general flow of work served as the basis for comparing various TDB-software packages available on the market. Technical data were taken from the market surveys of Pulitano and de Bessé (1989), Mayer from the University of the Saarland (1990) and Friedrich, Gerstenkorn, Hetschold from the University of Frankfurt (1991). Many packages were eliminated right away as they could handle no more than two llanguages per glossary. Of the remaining packages two were singled out, Term-PC and Multiterm, as they seemed to meet most of the requirements stipulated by interpreters, although both were in the upper price range ( $\$ 900$ - $\$ 1800)$.

Following are some of the main features of the two packages:

- implementation on PC, XT, AT with hard disk, 640 KB RAM

- operating system MS-DOS

- ability to handle at least three languages per glossary

- structure of entry can be defined freely (dynamic field lengths)

- retrieval of entries from any language via full entry, short stroke or keyword

- selection of terms according to any specified category (domain)

- convertibility for import/export of terminology

a print-out according to user specifications (Multiterm has interface to Ventura DTP, TERM-PC offers a considerable variety of formatting options) 
Not considered were:

- integration with various word processing packages

- ease of integration between TDB and word processing (pasting of terms into translation)

- windowing capabilities

networking capabilities

Although the latter are extremely important criteria for translation, they usually have little or no bearing on the work and needs of an interpreter, unless the interpreter is also a translator.

While the two packages met almost all requirements stipulated by interpreters, neither of them offers (at the time this study was completed in January of 1992) additional character sets for non-Latin characters.

Given the fact that today most notebook computers provide sufficient memory capacity and speed to respond to the demands of interpreters, that via modem the interpreter can access resources hitherto out of reach for her, that integrated fax capabilities allow her to receive information even at the last minute, thus changing perhaps some of her ingrained work habits, it is no surprise that professionals have become more demanding with regard to the functions they would like to see implemented. While limited, albeit functional, versions of terminology management tools can be programmed by most computer-literate interpreters (Gile, 1987), more powerful and more efficient tools can and must be developed so that the interpreter can become more economical in dealing with increasing amounts of information and thus ultimately provide a better service.

\section{NOTES}

1. The author wishes to thank all AIIC colleagues who have generously given of their time to complete and return the questionnaires and to Peter Moser of Stadt- und Regionalforschung in Vienna for statistical support.

\section{BIBLIOGRAPHY}

ALTMAN, H. Janet (1984): "Documentation and the free-lance interpreter", The Incorporated Linguist, Vol. 23/2, Spring 1984, pp. 82-85.

Association for Terminology and Knowledge Transfer (1988): Documentation-terminologie pour interprètes, recherche de lignes directrices, Manuscript, Vienna, Infoterm.

CLAS, André (1987) : "Les nouveaux lexiques ou une stratégie de création de mini-banques", Meta, Vol. $32 / 2$, pp. 212-215.

CZAP, H. and C. GALINSKI (1988): Terminology and Knowledge Engineering, Frankfurt, Indeks Verlag.

FRIEDRICH, M., GERSTENKORN, A., HETSCHOLD, T. (1991): "Terminologieverwaltungssysteme. Ergebnisse einer Umfrage", Mitteilungsblatt für Dolmetscher und Übersetzer (BDÜ), 4, pp. 3-5.

GILE, Daniel (1983) : "Les petits lexiques informatisés: quelques réflexions", AIIC Bulletin, XI/3, 9.

GILE, Daniel (1987) : "La terminotique en interprétation de conférence : un potentiel à exploiter", Traduire, 132/7, pp. 25-30.

GLE, Daniel (1990) : "Les ordinateurs portatifs : situation et perspectives", AIIC Bulletin, XVIII/1, 4, pp. 15-16.

International Organization for Standardization (1987): MATER (Magnetic Tape Exchange Format for terminological and lexicographical records), ISO Standard 6156, Geneva.

MAYER, F. (1990): “Terminologieverwaltungssysteme für Übersetzer. Ergebnisse einer Untersuchung", Lebende Sprachen, 3, pp. 106-114.

MOSER-MERCER, Barbara (1987): "Man/machine interface in translation and terminology", META, Vol. 32/2, pp. 156-163.

MOSER-MERCER, Barbara (to appear in 1992): "Terminology and documentation for conference interpreters", Proceedings of the Colloquium Phraséologie et terminologie en traduction et en interprétation, Bruno de Bessé (ed.), Brussels, Commission of the European Communities. 
PULITANO, D. and B. DE BESSÉ (1989): Computerm, Terminologiedatenbanken und computergestützte Übersetzungssysteme als Bestandteil der modernen Bürokommunikation, Geneva, École de traduction et d'interprétation.

QUICHERON, J. B. (1984) : "Mieux interpréter aux congrès techniques, un défi inaccessible?", Lebende Sprachen, 1, pp. 5-7.

SCHNEIDER, Th. (1987): "Terminotics of the future", META, 32/2, pp. 205-211.

SPSS-X (1992): Statistical Package for the Social Sciences, release 3.0 for HP-UX.

\section{Graph 1}

Years of professional practice

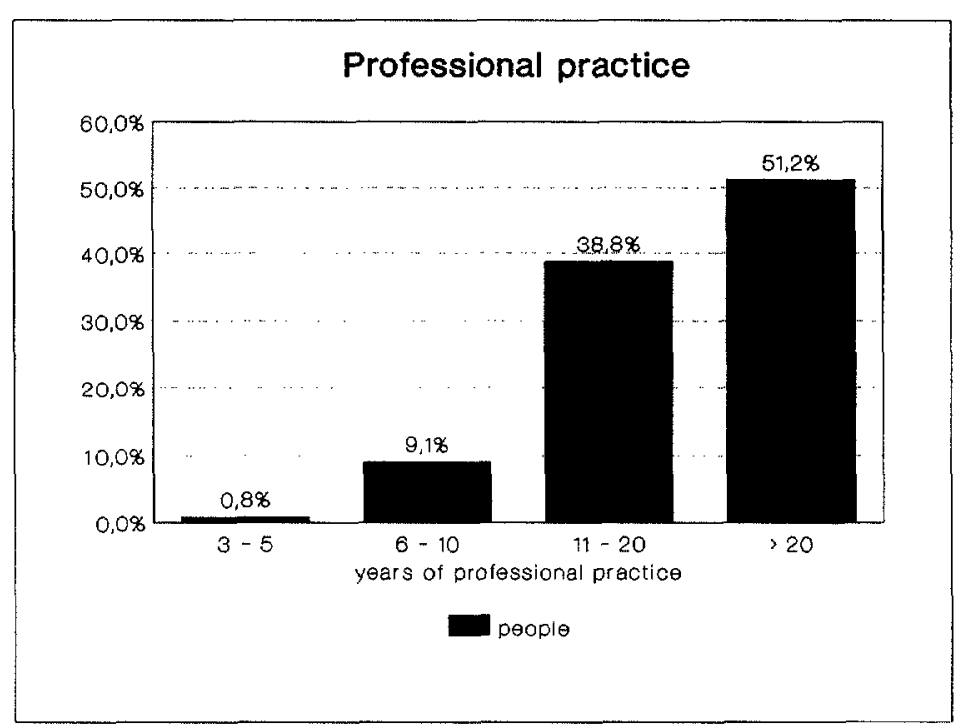

Graph 2

Interpreting days per year

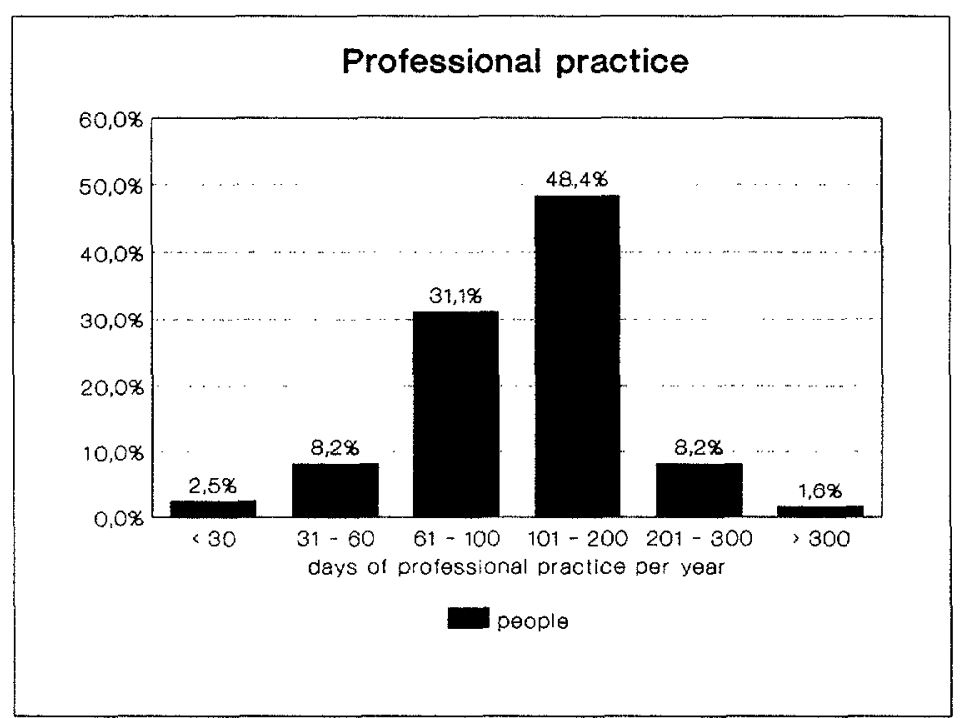


Graph 3

Computer users

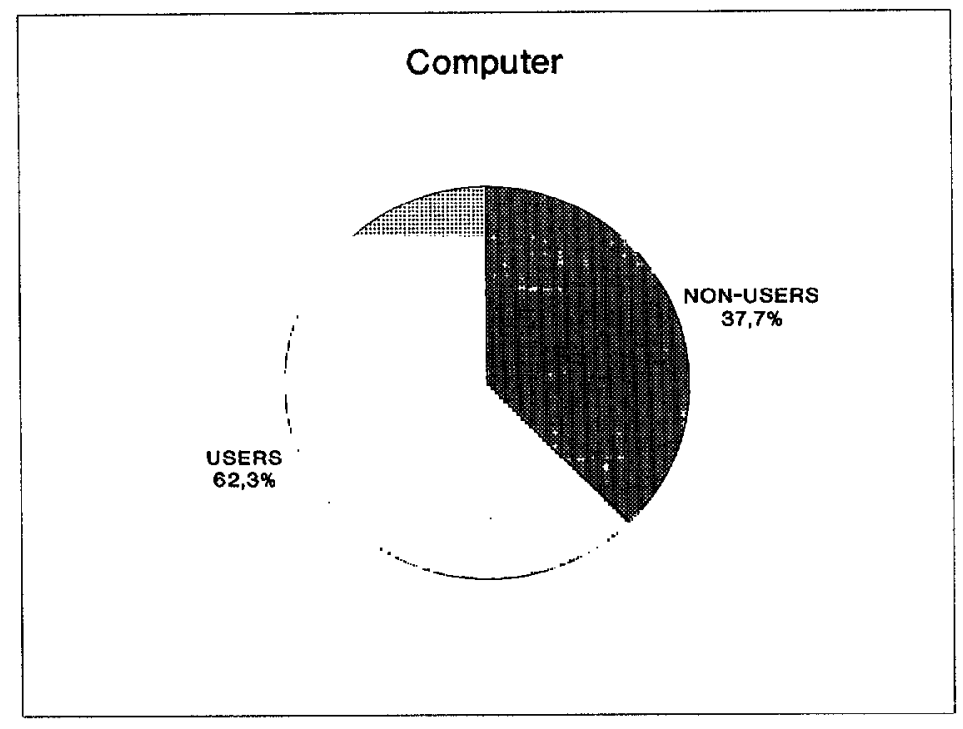

Graph 4

Fields of specialization

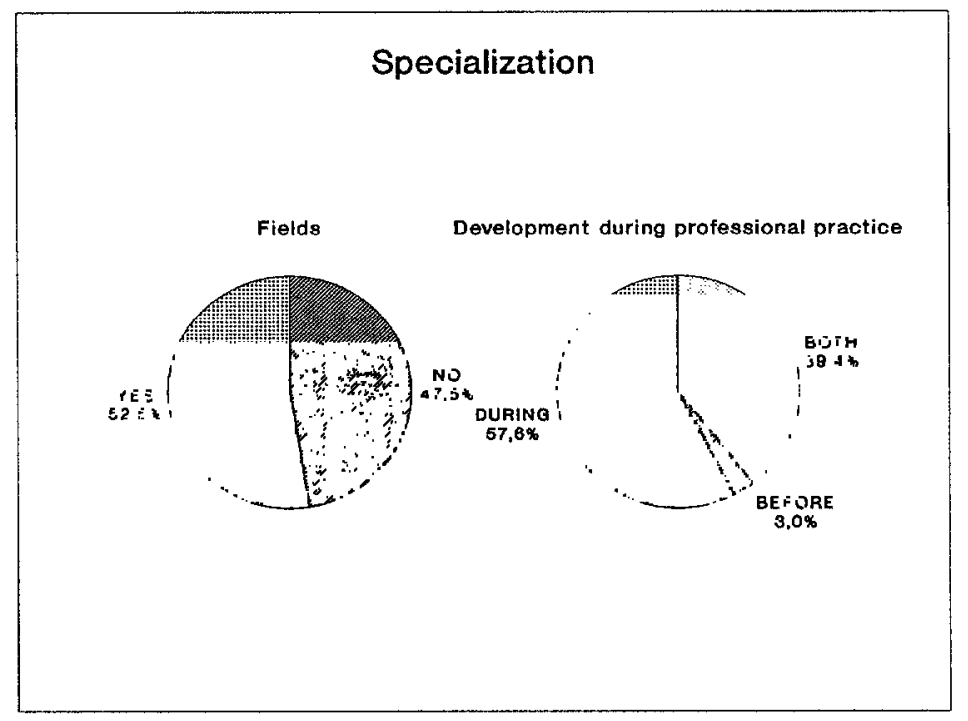


Graph 5

Documentation received in advance

Documentation in advance

Graph 6

Documents received

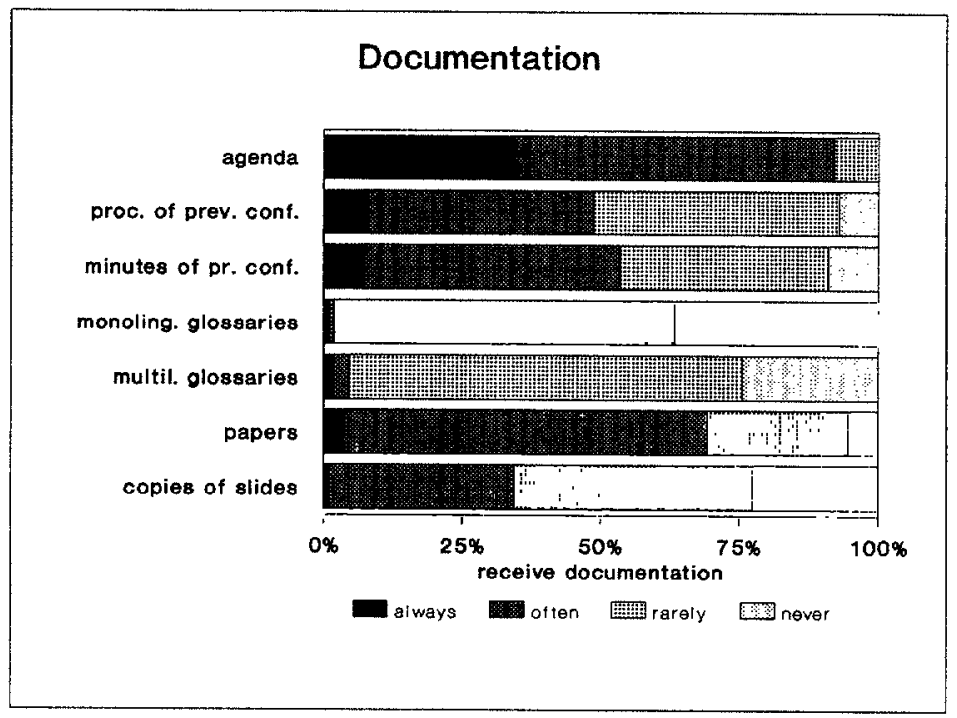


Graph 7

Participation in briefing sessions

Participation in briefing sessions

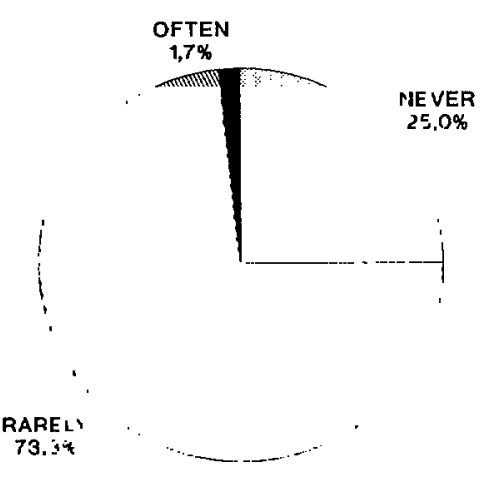

Graph 8

Documents of past conferences

Documents of past conferences

Keep documents

NO

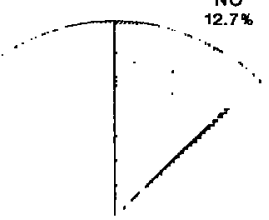

ES 
Graph 9

\section{Document management}

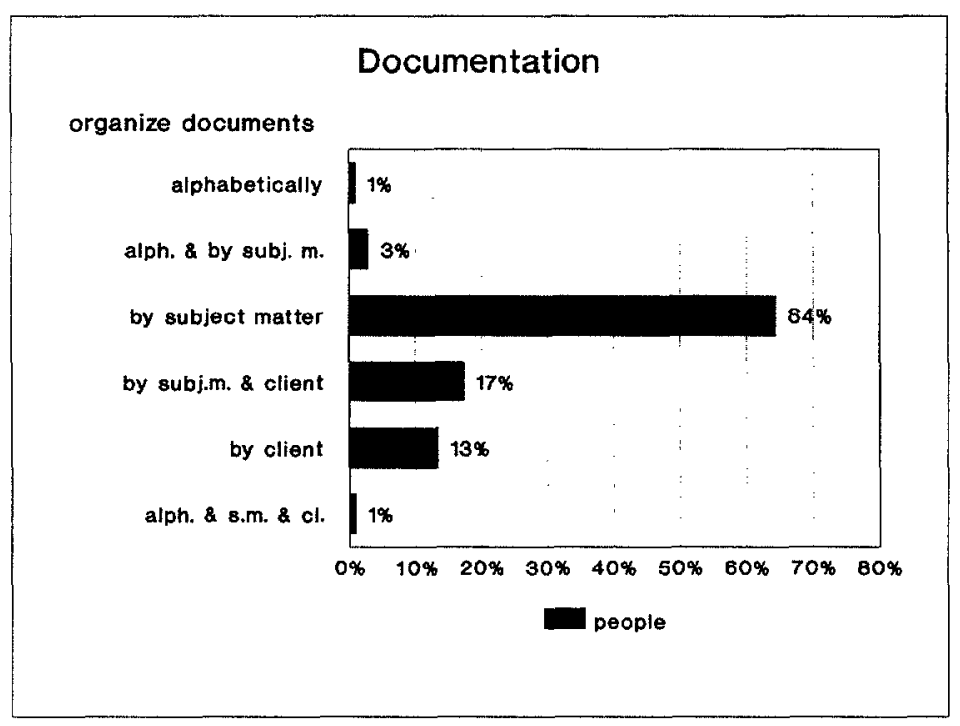

Graph 10

Housekeeping

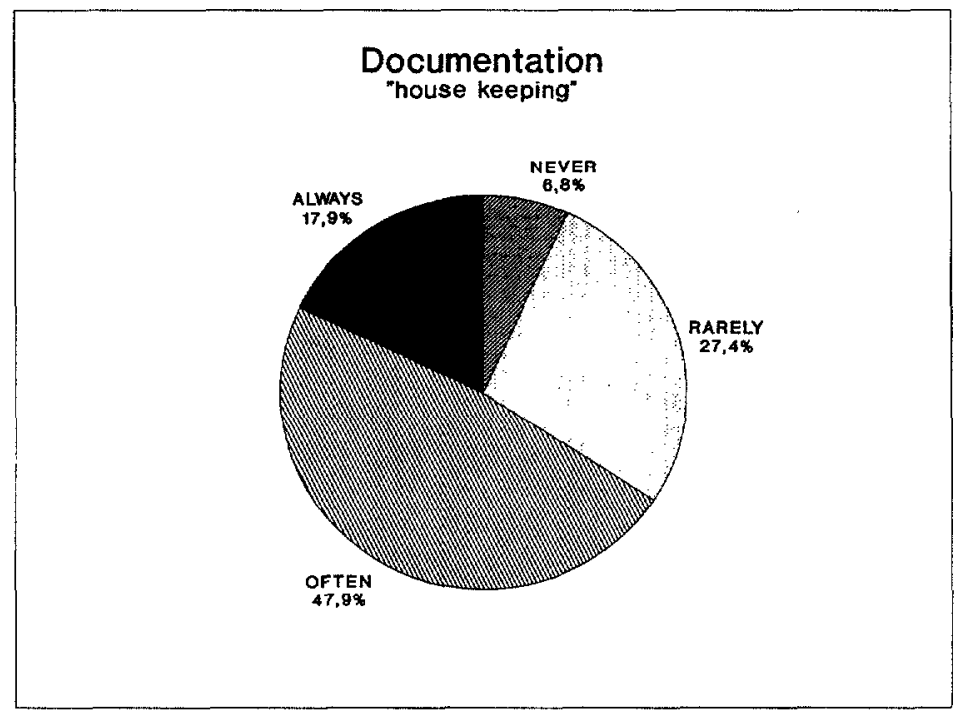




\section{Graph 11}

Interest in document control software and electronic communication

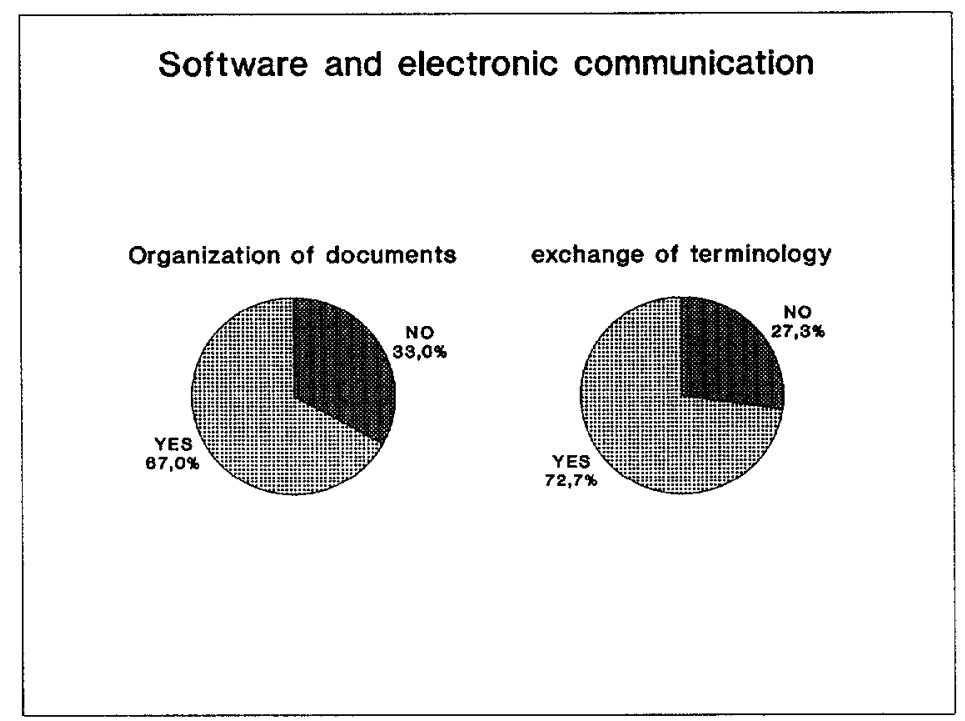




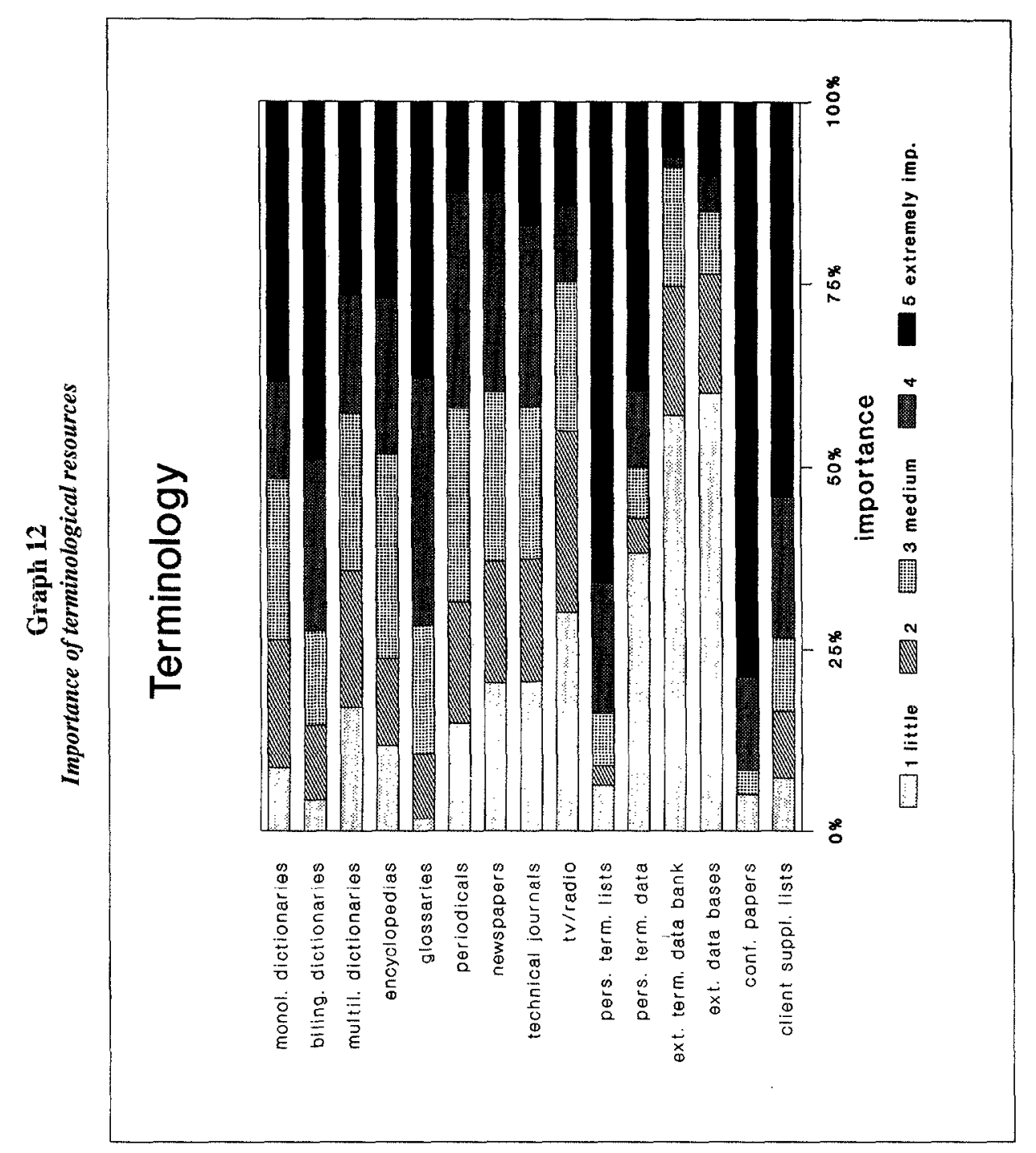


Graph 13

Users of external TDBs

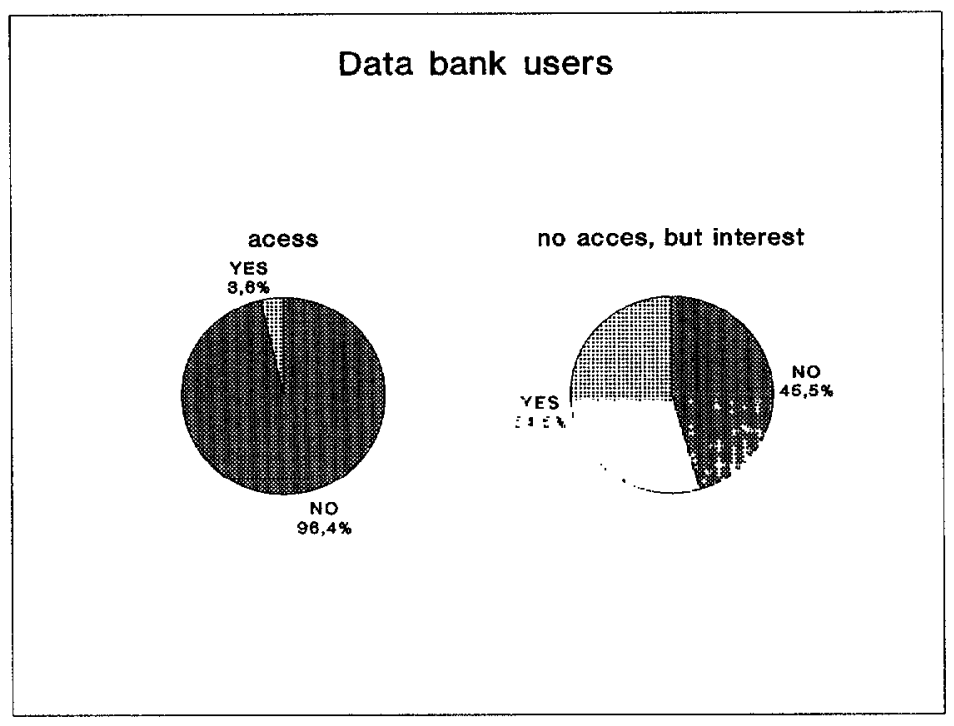

Graph 14

Type of computer used

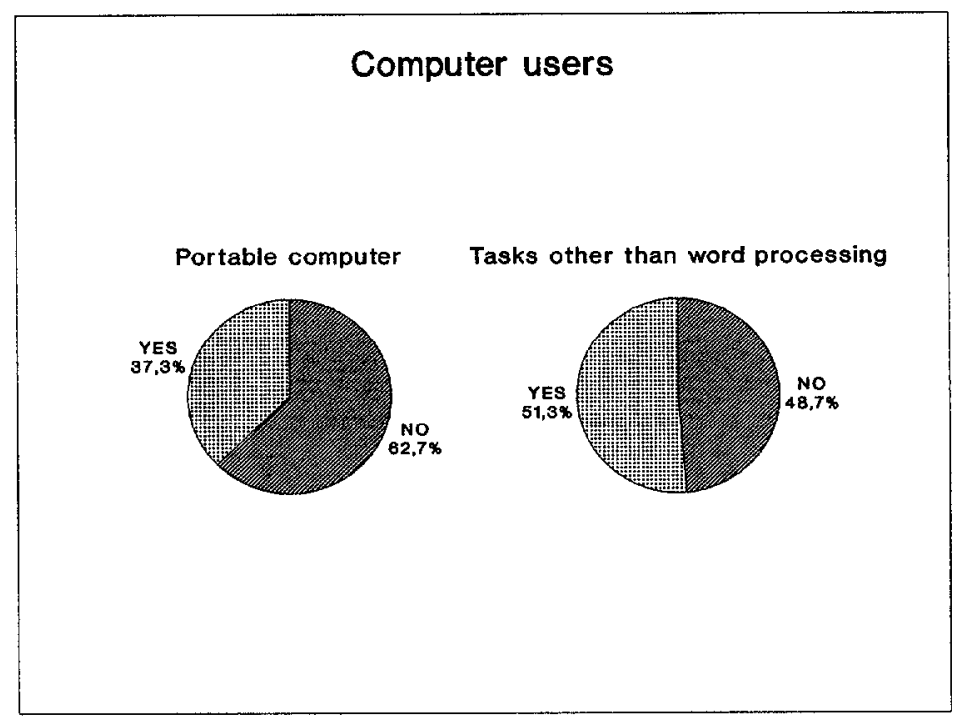


Graph 15

Software run

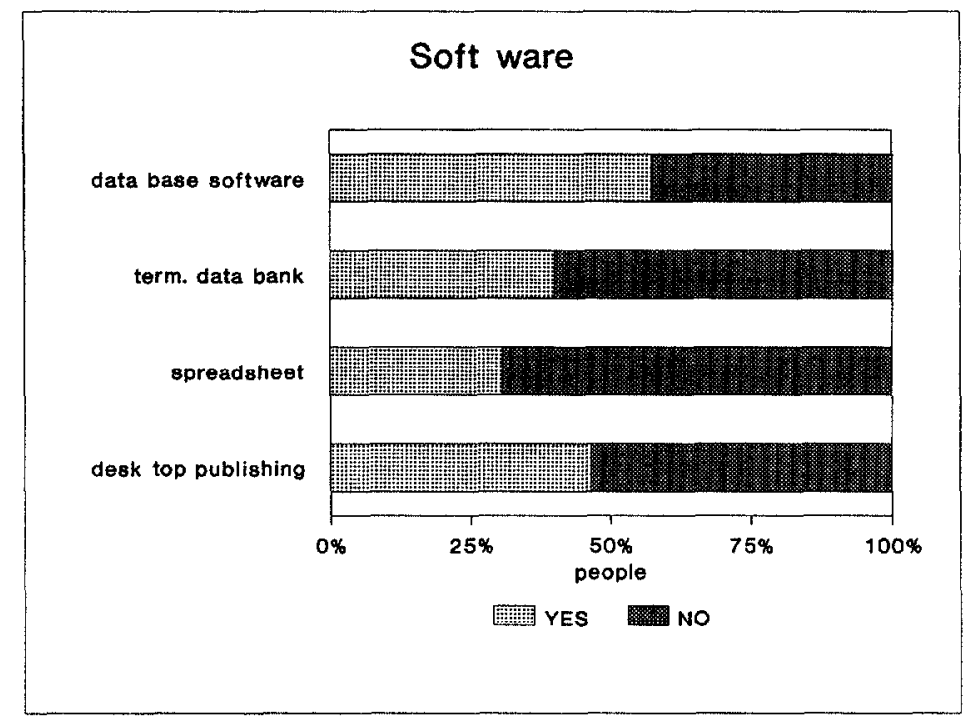

\section{Graph 16}

$T D B$ software: fields requested

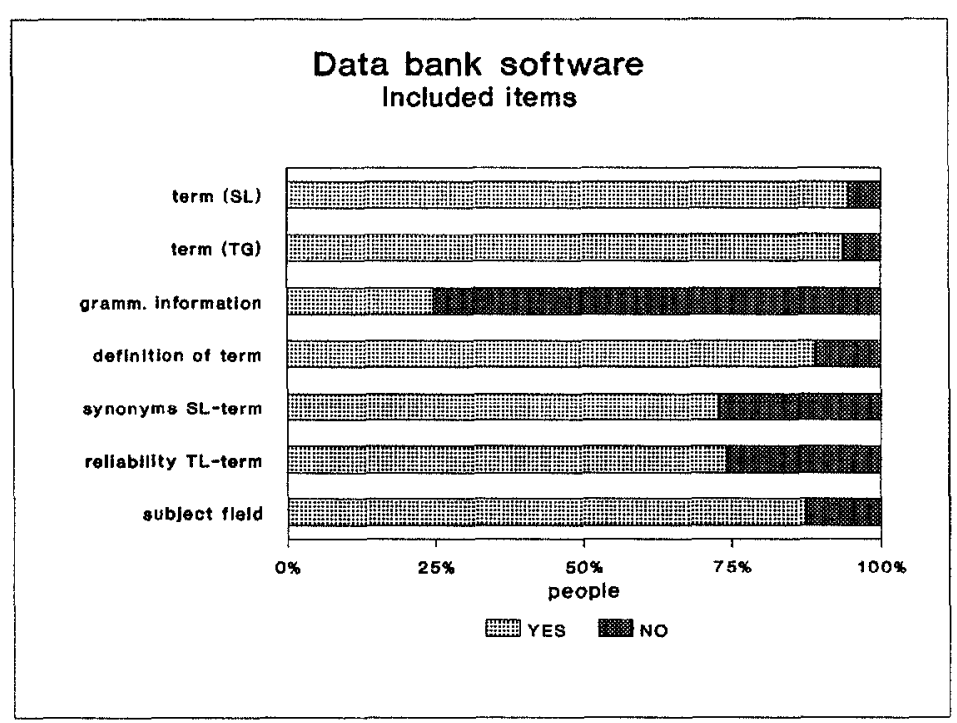




\section{Graph 17}

TDB software: functions requested

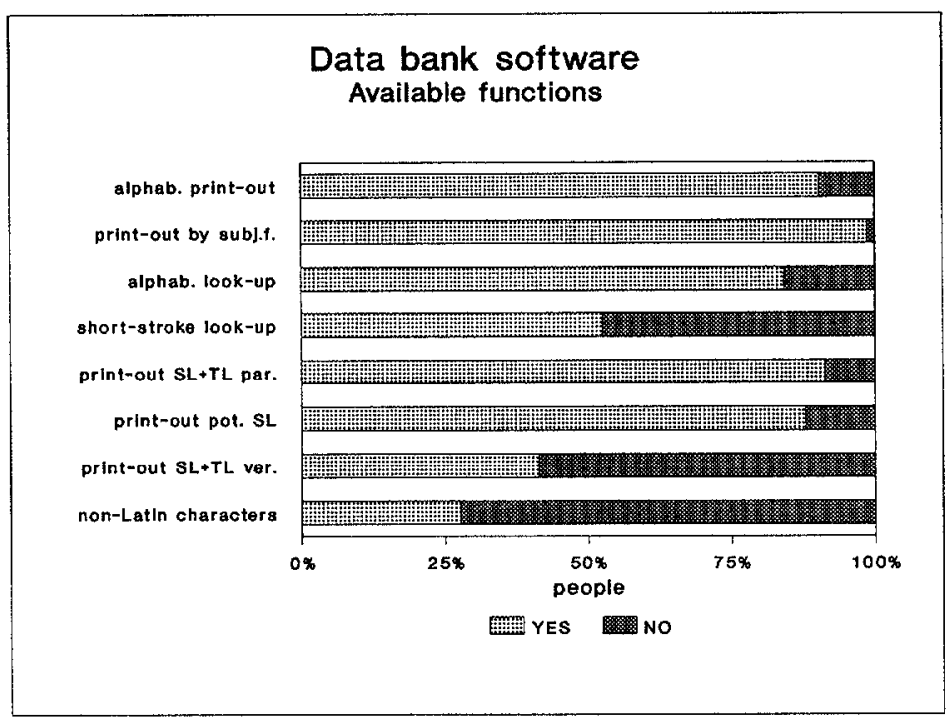

